\title{
UPAYA PENINGKATAN PEREKONOMIAN KELUARGA MELALUI IMPLEMENTASI KAMPUNG TEMATIK DI KELURAHAN PADANG NANGKA KECAMATAN SINGARAN PATI KOTA BENGKULU
}

\author{
Ovita Charolin ${ }^{1}$, Faridah $^{2}$, Supawanhar $^{3}$, Romdana $^{4}$ \\ Sekolah Tinggi Ilmu Administrasi Bengkulu, Jalan Cimanuk KM 6,5 Kota Bengkulu \\ Inacharol@gmail.com, faridahbaidjuri56@gmail.com, supawanhar103@gmail.com, \\ romdanayahya123@gmail.com
}

\begin{abstract}
ABSTRAK
Kemiskinan pada umumnya didefinisikan dari segi ekonomi, khususnya pendapatan dalam bentuk uang ditambah dengan keuntungan-keuntungan nonmaterial yang diterima oleh seseorang. Kemiskinan memang kerap melanda di beberapa negara-negara berkembang tak terkecuali di Indonesia dan sering kali dikaitkan dengan kesejahteraan. Semakin tinggi angka kemiskinan di suatu wilayah atau negara semakin rendah juga tingkat kesejahteraannya begitu pula sebaliknya, semakin rendah angka kemiskinan semakin tinggi juga tingkat kesejahteraan masyarakatnya. Untuk mendukung program pemerintah kota Bengkulu tahun 2018 mulai mencanangkan dibentuknya kampung tematik yang bertujuan untuk meningkatkan kesejahteraan masyarakat melalui peningkatan potensi dan identitas lokal. Kampung tematik yang di programkan oleh pemerintah kota bengkulu akan di gali potensinya melalui perguruan tinggi yang didukung oleh stimulus dari pemda kota bengkulu.

Tujuan dari artikel ini adalah untuk mengetahui peran kampung tematik dalam upaya meningkatkan pendapatan keluarga dengan memanfaatkan dan memaksimalkan potensi yang ada. Hal ini dapat dilihat dari praktik pelaksanaan kampung tematik serta efektifitasnya bagi peningkatan ekonomi. Metode yang digunakan adalah sosialisasi gerbang hebat kampung tematik sebagai wadah peningkatan pendapatan masyarakat lokal, sosialisasi perubahan/mindset pola pikir masyarakat, pelatihan aneka usaha kuliner, pelatihan aneka cinderamata, pembentukan kelompok wirausaha kuliner dan cinderamata., pembentukan kampung tematik Wirausaha sangat bermanfaat sekali bagi keberlangsungan peningkatan ekonomi yang ada di masyarakat. Selama ini usaha - usaha rumahan sudah ada dalam masyarakat akan tetapi belum dibina secara maksimal sehingga masyarakat sangat minim mendapatkan bantuan modal usaha, ataupun pemasaran dari produk-produk rumahan mereka. Pembentukan kampung tematik menjadi hal yang sangat penting untuk menunjang pendapatan masyarakat. Hasil yang dicapai dari kegiatan pengabdian kepada masyarakat ini adalah Tercapainya sosialisasi kepada warga tentang gerbang hebat kampung tematik sebagai wadah peningkatan perekonomian masyarakat setempat terkhusus kelurahan padang nangka kecamatan singaran pati, Tercapainya perubahan mindset/pola pikir masyarakat tentang pentingnya peran serta partisipasi masyarakat dalam meningkatkan ekonomi warga dengan memaksimalkan potensi yang dimiliki, Tercapainya kelompok-kelompok usaha kuliner , cinderamata, obat-obatan/jamu-jamuan tradisional di kampung wirausaha yang diberikan fasilitas wadah/outlet untuk memasarkan hasil olahan/produk usaha, Tercapainya publikasi kegiatan pendampingan kampung tematik "kampung wirausaha" melalui media online/massa, Tercapainya publikasi ilmiah di jurnal pengabdian masyarakat diperguruan tinggi swasta/negeri.
\end{abstract}

Kata Kunci : Kampung Tematik, peningkatan Ekonomi, Kewirausahaan 


\section{Ourralem}

\section{Pendahuluan}

Pertumbuhan dan perkembangan penduduk yang saat ini terjadi pada kotakota di negara berkembang seperti Indonesia merupakan imbas dari tingginya arus urbanisasi. Seiring dengan perkembangannya, kawasan perkotaan mengalami berbagai permasalahan yang kompleks seperti tingginya laju pertumbuhan penduduk, permasalahan penyediaan pemukiman dan sarana prasarana serta kemiskinan tidak pernah lepas dari kehidupan perkotaan. Penyediaan pemukiman beserta sarana dan prasarana pendukungnya hampir selalu tertinggal dibandingkan dengan kecepatan laju pertumbuhan penduduk. Selain itu, meningkatnya tekanan dan kebutuhan penduduk kota terhadap hunian juga turut menyebabkan meningkatnya harga lahan di kawasan perkotaan. Akibatnya, muncul kawasan-kawasan pemukiman perkotaan yang memiliki kepadatan tinggi dan berpotensi menimbulkan berbagai permasalahan di antaranya adalah keterbatasan pemenuhan sarana dan prasarana pendukung pemukiman perkotaan serta dapat berimbas pada permasalahan perekonomian yaitu kemiskinan.

Kemiskinan pada umumnya didefinisikan dari segi ekonomi, khususnya pendapatan dalam bentuk uang ditambah dengan keuntungan - keuntungan nonmaterial yang diterima oleh seseorang. Kemiskinan memang kerap melanda di beberapa negara-negara berkembang tak terkecuali di Indonesia dan sering kali dikaitkan dengan kesejahteraan. Semakin tinggi angka kemiskinan di suatu wilayah atau negara semakin rendah juga tingkat kesejahteraannya begitu pula sebaliknya, semakin rendah angka kemiskinan semakin tinggi juga tingkat kesejahteraan masyarakatnya (Usman,2006).

Kampung tematik belakangan ini terlihat menjamur dan menjadi daya tarik bagi masyarakat khususnya di kota
Bengkulu, Seiring dengan dicanangkannya program pemerintah yang berupaya untuk merubah kampung-kampung kumuh menjadi kampung yang bersih, dengan salah satu programnya membentuk kampung tematik, dan masih banyak lagi kampung-kampung lain yang bisa diangkat menjadi kampung tematik. Disamping itu kampung tematik ini bisa menjadi kampung destinasi wisata yang menarik bagi wisatawan domestik tidak menutup kemungkinan wistawan mancanegara juga akan tertarik mengunjungi kampung tematik.

Kampung tematik ini berbagai macam tema nya, tergantung potensi kampung yang bisa dikembangkan. Hal ini karena membentuk kampung tematik harus diupayakan mengangkat potensi daerah. Berbagai macam tema bisa dibentuk untuk mewujudkan kampung tematik yang menarik, misalnya tematik batik, wirausaha, agro, seni, budaya, ramah anak, dan lain sebaginya. Apapun temanya, kampung tematik dibentuk memiliki tujuan yang positif utamanya yaitu membuat lingkungan rumah tinggal warga masyarakat lebih berkualitas dan lebih nyaman selain juga bisa meningkatkan kesejahteraan warga nya. Dengan adanya kampung tematik masyarakat bisa memiliki usaha yang macam-macam antara lain berjualan makanan atau minuman untuk menyambut wisatawan yang datang mengunjungi kampung tematiknya. Dengan demikian masyarakat memiliki kegiatan tambahan yang positif disamping bisa menambah pendapatan keluarga. Dengan adanya kampung tematik yang berada dalam lingkungan masyarakat, membuat masyarakat lebih dapat menggali potensipotensi yang ada dalam lingkungannya untuk dapat meningkatkan perekonomian mereka.

Konsep pelaksanaan kampung tematik berdasarkan skema inovasi sosial memiliki tiga tahapan, antara lain: 


\section{Ourralem}

1. Tahap pertama, merupakan pemetaan problematika yaitu masyarakat bersama mencari ide atau gagasan dalam mengembangkan kampungya sehingga dapat menciptakan lapangan pekerjaan serta meningkatkan pertisipasi masyarakat lokal.

2. Tahap kedua adalah menentukan tema kampung dengan menemukan sekelompok orang yang tertarik dan mau untuk bekerjasama dalam menerapkan gagasan atau tema pada kampungnya.

3. Dan tahap yang terakhir adalah delineasi dan koordinasi program melalui gagasan atau tema yang kemudian dimodifikasi oleh beberapa aktor yang terlibat hingga akhirnya diimplementasikan secara nyata pada wilayahnya. Hal ini juga dapat dipengaruhi oleh faktor-faktor seperti karakteristik ekonomi, sosial, adanya potensi lokal yang diangkat, dukungan keuangan dari pihak luar, inisiatif dari pihak tokoh masyarakat, meningkatnya pendapat dan inisiatif dari masyarakat. (Atkociuniene \& Kaminaite, 2017).

Menurut Fosso \& Kahane (2013), suatu konsep pengembangan kawasan seperti kampung tematik dapat mencapai hal yang positif apabla masyarakat dapat berpartisipasi dan melihat dampak dampak positif, potensi peningkatan hingga kemungkinan pendapatan yang dapat dihasilkan. Penelitian yang dilakukan oleh Kloczko-Gajewska(2014) menunjukan bahwa kampung tematik yang berhasil merupakan kamung yang melibatkan kelompok masyarakat untuk dapat mengimplementasikan tema yang sesuai dengan kampungnya. Sebaliknya, kampung tematik dapat dikatakan tidak berhasil apabila dilihat dari ketidakikutsertaan masyarakat dalam implementasi tema sehingga akhirnya tema itu tidak berjalan hingga ditinggalkan.

Untuk mendukung program pemerintah kota Bengkulu tahun 2018 mulai mencanangkan dibentuknya kampung tematik yang bertujuan untuk meningkatkan kesejahteraan masyarakat melalui peningkatan potensi dan identitas lokal. Kampung tematik yang di programkan oleh pemerintah kota bengkulu akan di gali potensinya melalui perguruan tinggi yang didukung oleh stimulus dari pemda kota bengkulu. Salah satu fokus program pemerintah pun terdapat di Kelurahan Padang Nangka berada di RT $.15 \mathrm{Jl}$. Tutwuri Handayani, salah satu yang menonjol adalah usaha-usahan rumahan ibu-ibu sekitar yang menjadikannya sebagai Kampung Tematik, sehingga RT 15 disebut sebagai Kampung Wirausaha.

Selama ini di Kelurahan Padang Nangka sudah ada beberapa Usaha-usaha rumahan, seperti usaha pengolahan makanan ringan, cinderamata, pembuatan minuman, dan oabt-obatan tradisional. Akan tetapi usaha-usaha rumahan itu belum terbina dengan baik karena belum banyak mendapat perhatian secara khusus. Setelah ada anjuran dari pemerintah kota akan adanya kampung tematik, maka masyarakat, pemerintah daerah dibantu oleh pihak perguruan tinggi dalam hal ini Sekolah Tinggi Ilmu Administrasi Bengkulu , membangkitkan kembali Usahausaha rumahan di kelurahan padang nagka dengan dicanangkannya kampung Wirausaha sebagai kampung Tematik.

\section{METODE KEGIATAN}

Kegiatan pendampingan kampung tematik ini sudah dilakukan dalam bentuk kegiatan : sosialisasi gerbang hebat kampung tematik sebagai wadah peningkatan pendapatan masyarakat lokal, sosialisasi perubahan/mindset pola pikir masyarakat, pelatihan aneka usaha kuliner, pelatihan aneka cinderamata, pembentukan kelompok wirausaha kuliner dan cinderamata. Tiap tahapan tersebut selalu di ikuti lebih dari 25 orang ibu-ibu warga bersama koordinator kampung tematik. 


\section{Ourralem}

Adapun kegiatan pendampingan kampung tematik yang dilakukan adalah secara rinci sebagai berikut :

Tahapan I, pada tahapan ini tim pendampingan melakukan beberapa kegiatan awal sebagai berikut :

1. Mendatangi kecamatan Singaran Pati dan Kelurahan Padang nangka serta berdiskusi dengan pak camat dan bu lurah terkait kegiatan pendampingan yang akan dilakukan

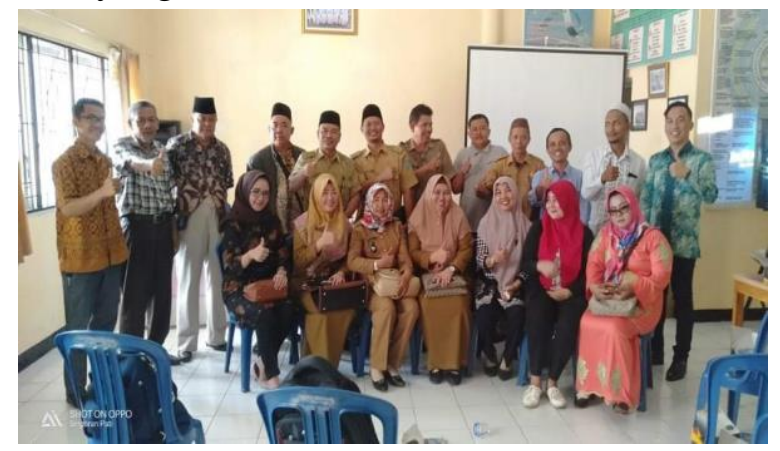

Gambar 1

2. Mendatangi ke lokasi kelurahan padang nangka dan berdialog dengan warga yang akan dibentuk dan didampingi pembentukan kampung tematik

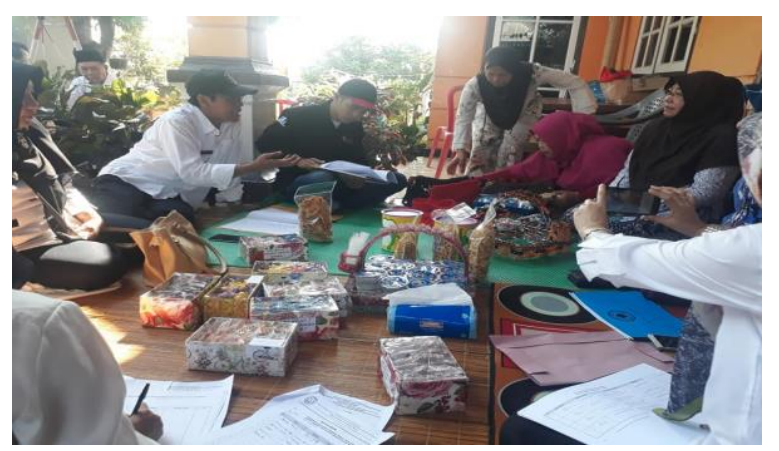

Gambar 2

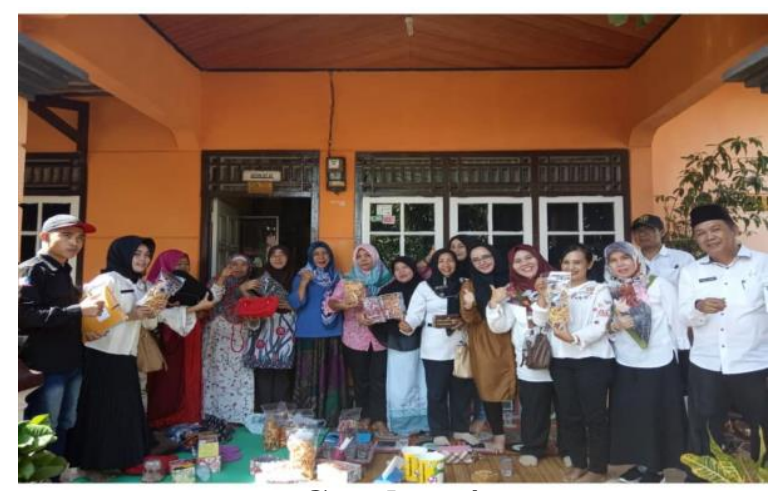

Gambar 4
3. Menyusun proposal kegiatan kampung tematik

Penyusunan proposal desain yang di usulkan kepada pemerintah kota bengkulu, dalam hal ini Bapelitbang kota Bengkulu berupa :

a. Latar Belakang

Maksud dan tujuan

b. Analisis Situasi

- uraian kompetensi wilayah yang akan diusulkan menjadi Kampung tematik

- Uraian permasalahan yang ada di wilayah yang akan di usulkan menjadi kampung tematik

- Hal-hal apa saja yang ingin dirubah beserta alasannya

c. Gambaran kondisi awal (foto kondisi lingkungan, foto kegiatan potensi masyarakat, foto permasalahan, foto produk unggulan)

d. Gambaran desaian yang diusulkan, berisi desain/gambar rencana dari kondisi yang diharapkan setelah pembangunn kampung tematik selesai

e. Rencana Anggaran dan Biaya (RAB)

f. Manfaat di bidang sosial/budaya, ekonomi, kesehatan, infrastruktur, dll

g. Penutup

Kesimpulan dan Saran

4. Bekerjasama dengan pihak pemerintah kota bengkulu terkhusus Bapelitbang kota bengkulu dalam pembinaan dan stimulus pembangunan kampung wirausaha

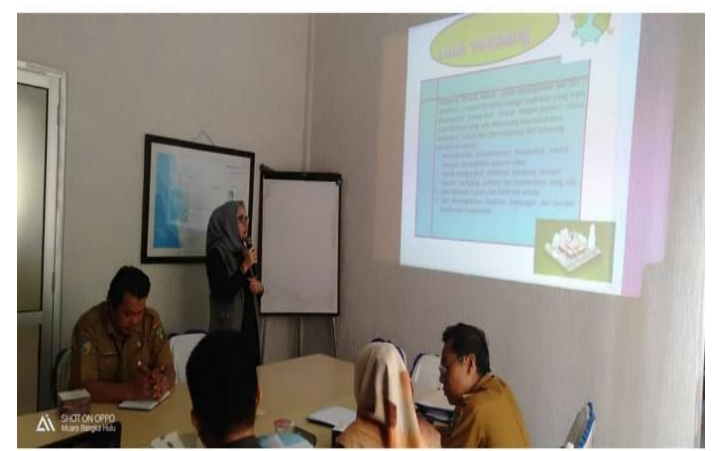

Gambar 5. Persentasi proposal pembangunan kampung tematik di Bapalitbang Kota Bengkulu 


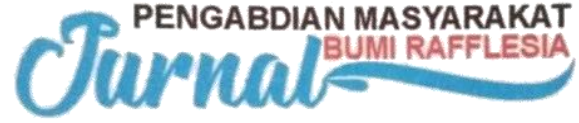

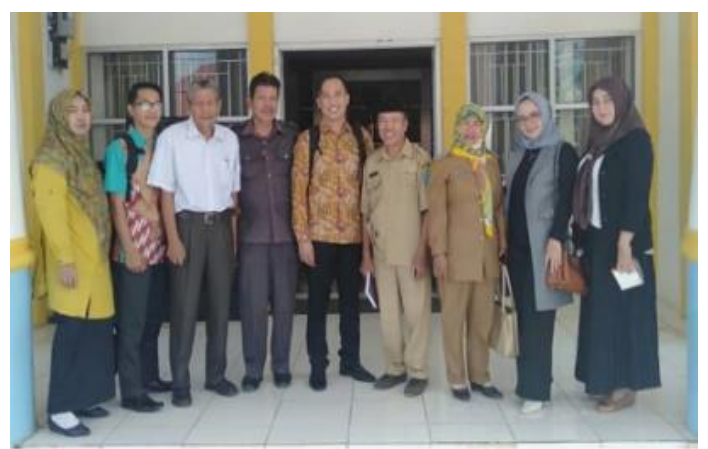

Gambar 6, kunjungan ke kantor Bapelitbang Kota Bengkulu

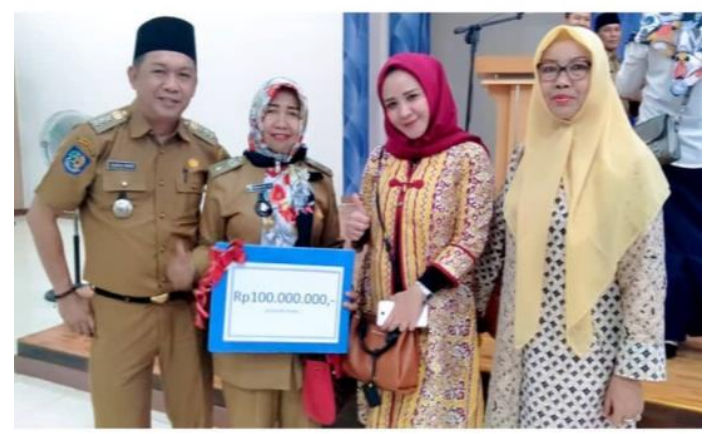

Gambar 7. Pemberian stimulus dari pemerintah kota Bengkulu

5. Membangun outlet hasil wirausaha warga kelurahan padang nangka
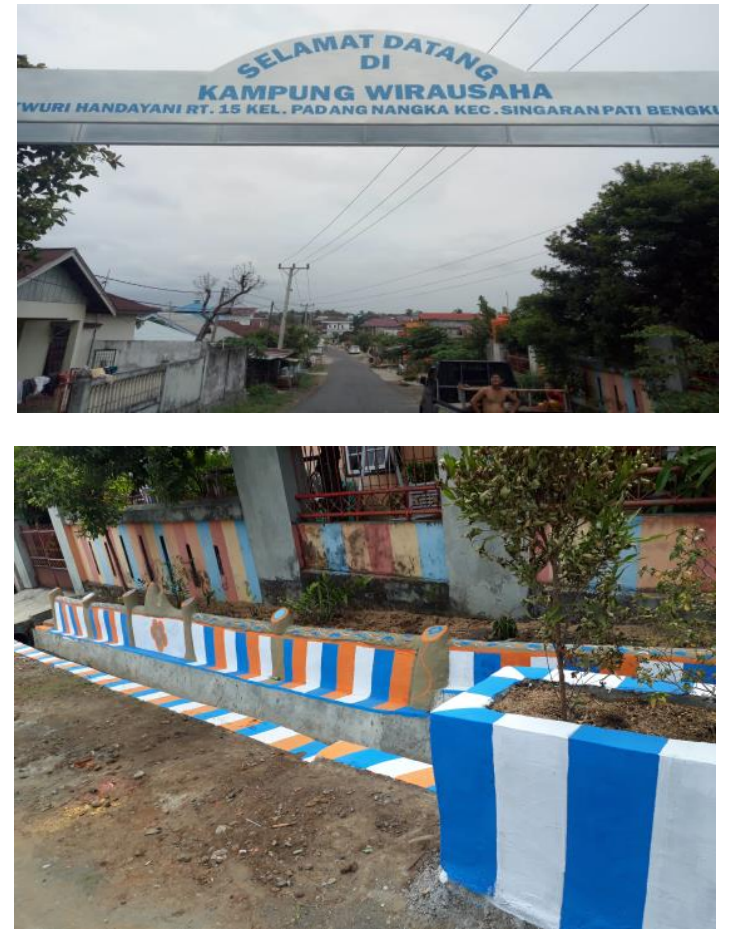

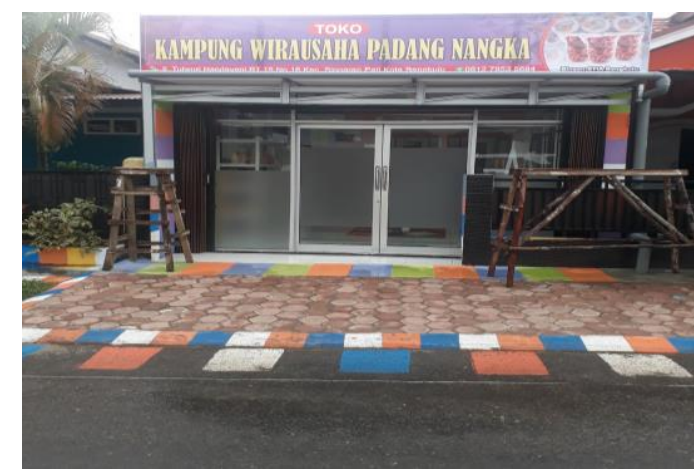

Gambar 8. Proses pembuatan outlet, gapura dan taman sepanjang jalan kampung wirausaha

Tahap II : Sosialisasi dan perubahan mindset pola pikir masyarakat

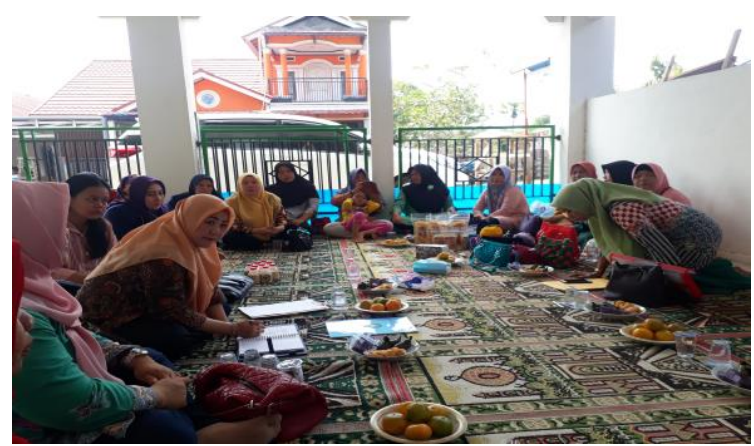

Gambar 9. Sosialisasi perubahan mindset pola pikir masyarakat

Sosialisasi perubahan mindset pola pikir masyarakat dihadiri oleh masyarakat Kelurahan Padang Nangka yang berjumlah sebanyak 25 orang. Pemateri di isi oleh tim dosen dari Sekolah Tinggi Ilmu Administrasi Bengkulu sebanyak 4 orang, dan didampingi dari pihak Bapelitbang kota Bengkulu. Masyarakat sangat antusias mengikuti sosialisasi yang diberikan, besar harapan mereka untuk selalu ada pendampingan dan pelatihan secara rutin agar masyarakat padang nangka termotivasi untuk berwirausaha dan meningkatkan ekonomi keluarga. 


\section{Orurnal=}

Tahap III : Pelatihan kuliner aneka makanan ringan dan aneka cinderamata
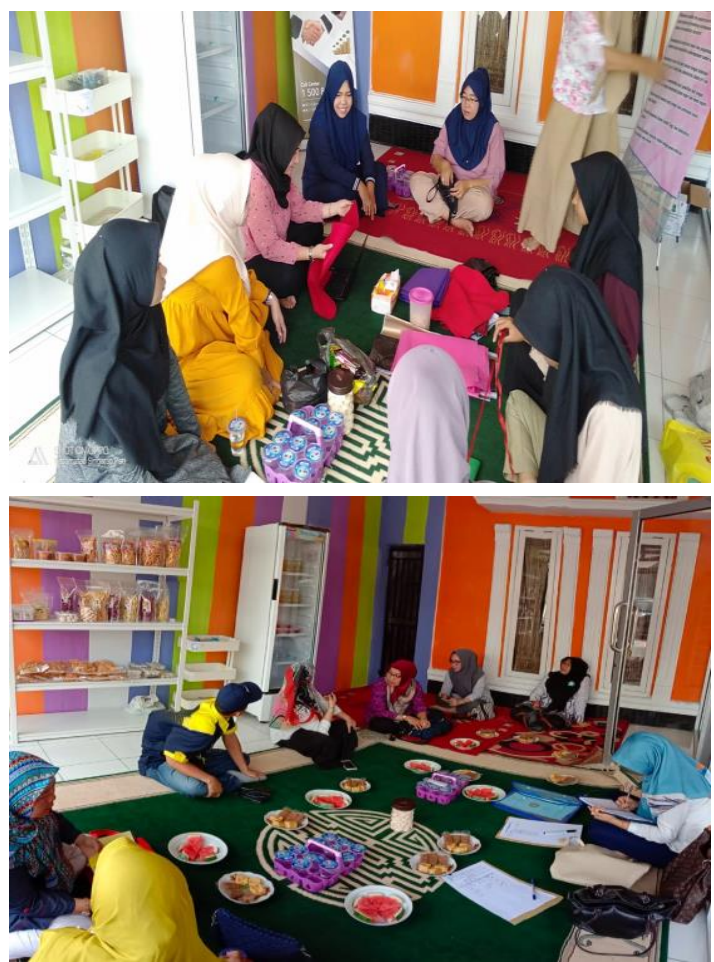

Gambar 10 \& 11

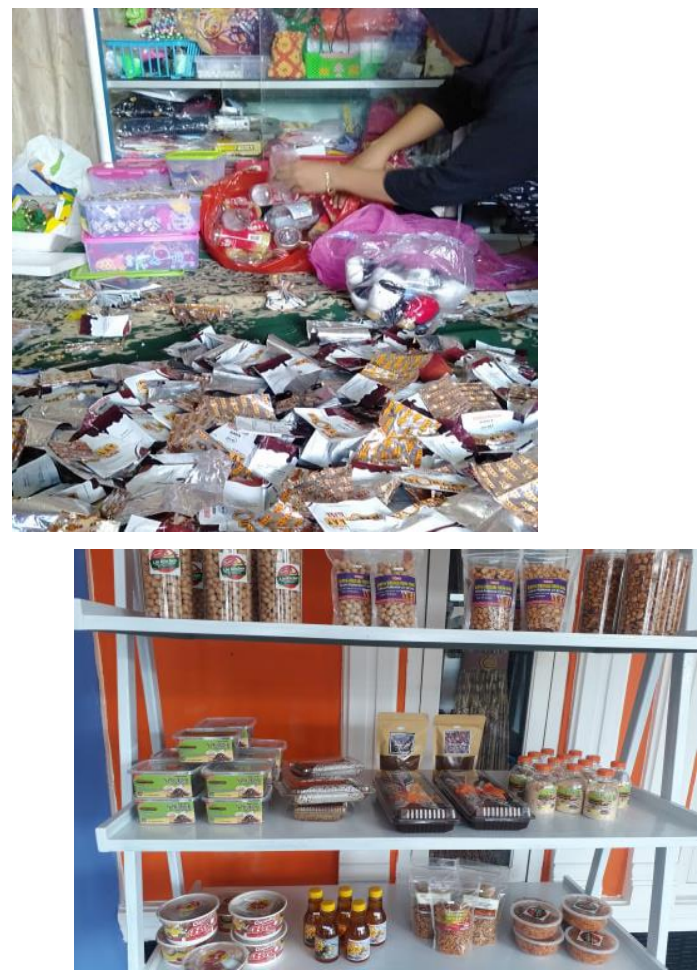

Gambar 12 \& 13

Pelatihan-pelatihan yang telah diterapkan kepada masyarakat kelurahan padang nangka kecamatan singaran pati menimbulkan dampak-dampak positif diantaranya masyarakat dapat menambah wawasan, Masyarakat dapat memahami analisa peluang usaha berwirausaha pembuatan kue kering dan berbagai cinderamata, Masyarakat mendapatkan manfaat dan dapat menggunakan produk yang dihasilkan, dan Masyarakat dapat menerapkan ilmu yang didapat untuk dijadikan sebagai ide kewirausahaan. Masyarakat harus terdorong untuk dapat membuka usaha-usaha baru baik dengan merintis sendiri, dengan keluarga, atau bekerjasama antara satu dengan yang lainnya dalam bentuk usaha yang kecil maupun yang besar

Tahap IV : Pembentukan kelompokkelompok usaha kuliner dan aneka cinderamata

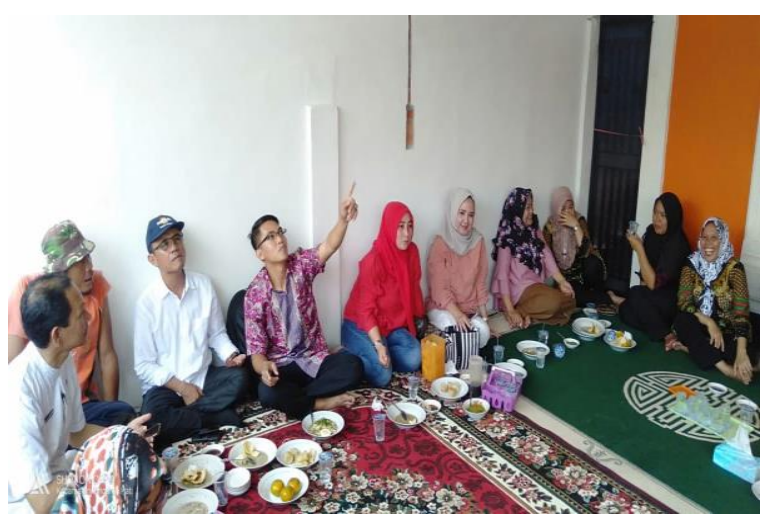

\section{Gambar 14. Pembentukan kelompok Usaha}

Setelah memberikan sosialisi perubahan mindset masyarakat dan pelatihan pembuatan kue dan cinderamata, tahap selanjutnya adalah pembentukan kelompok-kelompok usaha kuliner dan aneka cinderamata, tujuannya agar masingmasing kelompok terfokus dengan usaha yang sudah memang di geluti oleh masingmasing individu. Dan didalam satu kelompok minimal dua orang yang ditugaskan dibagian pemasaran dengan tugas promosi makanan kering dari berbagai bahan campuran kue kering dari media sosial baik faceboook, path, line, 


\section{Orurnal:}

whats upp, we chat,bbm, instagram juga situs jual beli online dan lainnya. Juga dapat pula menjalankan strategi pemasaran kue kering lewat menyebarkan berbagai brosur dan pasang spanduk. Pembentukan kelompok usaha dikelurahan padang nangka sejumlah 5 kelompok yang terdiri masing-masing kelompok 5 orang.

Tahap V : Evaluasi dan Penyusunan Laporan.

Evaluasi dan penyusunan laporan guna pertanggungjawaban ke pemerintah kota bengkulu, laporan akhir berupa laporan penggunaan anggaran pembangunan kampung tematik dan kegiatan yang telah berlangsung selama pendampingan pembangunan kampung tematik.

\section{Hasil Pengabdian Masyarakat}

Sesuai dengan target dan luaran yang telah ditetapkan oleh tim pendampingan kampung tematik "kampung Wirausaha", tim mendeskripsikan hasil yang dicapai selama pelaksanaan pendampingan sebagai berikut :

1. Tercapainya sosialisasi kepada warga tentang gerbang hebat kampung tematik sebagai wadah peningkatan perekonomian masyarakat setempat terkhusus kelurahan padang nangka kecamatan singaran pati

2. Tercapainya perubahan mindset/pola pikir masyarakat tentang pentingnya peran serta partisipasi masyarakat dalam meningkatkan ekonomi warga dengan memaksimalkan potensi yang dimiliki

3. Tercapainya kelompok-kelompok usaha kuliner, cinderamata, obat-obatan/jamujamuan tradisional di kampung wirausaha yang diberikan fasilitas wadah/outlet untuk memasarkan hasil olahan/produk usaha.

4. Tercapainya publikasi kegiatan pendampingan kampung tematik "kampung wirausaha" melalui media online/massa
5. Tercapainya publikasi ilmiah di jurnal pengabdian masyarakat diperguruan tinggi swasta/negeri

\section{Simpulan dan Saran}

Kegiatan pendampingan ini didasari rasa ingin membantu dan memberdayakan masyarakat kelurahan padang nangka, karena sebagian penduduknya adalah penggiat usaha rumahan yang belum mendapatkan fasilitas untuk memasrkan produk dan belum terbisa sebelumnya. Dengan adanya program pemerintah kota Bengkulu, maka wilayah kelurahan padang nangka yang terletak di RT.15 ini mendapatkan bantuan sebesar Rp.100.000.000,- untuk membenahi kampunya menjadi kampung yang lebih baik. Dengan bantuan dana tersebut kini kampung wirausaha RT.15 Keluarahan Padang nangka menjadi kampung yang bersih dan tertata rapi, dan mandiri, serta masyarakat dapat ebih produktif mengolah usaha-usaha mereka tanpa terkendala tempat penitipan produk atau uang sewa toko. Dari kegiatan yang sudah tim pendamping lakukan, maka tim dapat menyimpulkan sebagai berikut :

1. Kampung tematik "Kampung Wirausaha" perlu mendapatkan pendampingan secara rutin dan reguler guna membantu masyarakat dalam mengeloa kampung tematiknya.

2. Warga kampung wirausaha mendapatkan pelatihan lanjutan tentang pengelolaan usaha kuliner untuk membantu ekonomi keluarga

3. Kelompok-kelompok usaha yang sudah terbentuk perlu mendapatkan pendampingan dan pembinaan yang berkelanjutan dari berbagai pihak agar mereka menjadi kelompok wirausaha mandiri dan mampu menularkan embrio kelompok usaha yang lainnya.

4. Menurut tim pendampingan dari LPPM STIA Bengkulu atas kampung wirausaha ini, maka setelah melakukan evaluasi 
kegiatan dapat menyampaikan beberapa saran yaitu:

1. Pemerintah dapat memfasilitasi pelatihan dan pengemabangan produk UMKM secara rutin setiap tahunnya, menginat inisiasi kegiatan besar ini adalah salah satu program unggulan pemerintah kota bengkulu walikota Helmi Hasan.

2. Pemerintah dapat memberikan bantuan modal usaha bagi kelompok-kelompok usaha Kampung wirausaha, guna mengembangkan usaha mereka lebih maju lagi.

3. Untuk kampung Wirausaha kelurahan padang nangka memberikan ciri khas porduk olahan lokal , sehingga di kalangan masyarakat luar lebih mengenal keidentikan kampung wirusaha karena ciri khas tersebut .

4. Agar nantinya akan tumbuh kelompok-kelompok baru Wirausaha dikelurahan padang nangka.

\section{Ucapan Terimakasih}

1. Walikota Bengkulu

2. Bapelitbang Kota Bengkulu

3. Ketua STIA Bengkulu

4. Ketua LPPM STIA Bengkulu

5. Camat Singaran Pati

6. Lurah Padang Nangka

7. Bapak ibu warga kelurahan padang nangka "Kampung Wirasaha"

\section{DAFTAR PUSTAKA}

Akbar, S.P dan H.Usman.2006. Metode Penelitian Sosial.Bumi Askara. Jakarta.

Atkočiū nienè , V., \& Kaminaitè , G. (2017). The drivers of thematic village's development in strengthening their vitality. Management Theory and Studies for Rural Business and
Infrastructure Development, 39(2), 139147. doi:10.15544/mts.2017.10.Vol

Fosso, A., \& Kahane, R. (2013). Urban and peri urban horticulture in Namibia. ActaHorticulturae, 1007, 821-827. doi:10.17660/ActaHortic.2013.1007 .98

Jonnius, J. (2013) 'Menumbuh kembangkan Budaya Kewirausahaan dalam Masyarakat', Menara, 12(1), pp. 48-55.

Kloczko-Gajewska, A. (2014). Can we treat thematic villages as social innovations? Journal of Central European Green Innovation, 2(3), 49-59. Retrieved from https://ideas.repec.org/a/ags/hukrgr/ $\underline{188135 . h t m l}$.

Saragih, R. (2017) 'A Membangun Usaha Kreatif, Inovatif dan Bermanfaat Melalui Penerapan Kewirausahaan Sosial', Jurnal Keiwrausahaan, 3(2), pp. 26-34. Available at: http://jklmii.org. 